\title{
Flavobacterium antarcticum sp. nov., a novel psychrotolerant bacterium isolated from the Antarctic
}

\begin{abstract}
Correspondence Jongsik Chun jchun@snu.ac.kr
\end{abstract}

\author{
Hana Yi, ${ }^{1}$ Huyn-Myung Oh, ${ }^{1}$ Jung-Hyun Lee, ${ }^{2}$ Sang-Jin Kim ${ }^{2}$ \\ and Jongsik Chun ${ }^{1}$ \\ ${ }^{1}$ School of Biological Sciences, Seoul National University, 56-1 Shillim-dong, Kwanak-gu,
Seoul 151-742, Republic of Korea \\ ${ }^{2}$ Microbiology Lab, Marine Biology Division, Korea Ocean Research and Development Institute, \\ Ansan PO Box 29, Seoul 425-600, Republic of Korea
}

\begin{abstract}
A yellow-pigmented, Gram-negative and aerobic bacterial strain, designated AT1026 ${ }^{\top}$, was isolated from a terrestrial sample from the Antarctic. Results of 16S rRNA gene sequence analysis indicated that the Antarctic isolate belonged to the genus Flavobacterium, with the highest sequence similarity to Flavobacterium tegetincola (96.4\%). Cells were non-motile, non-gliding and psychrotolerant, with optimum and maximum temperatures of about 20 and $25{ }^{\circ} \mathrm{C}$.

Flexirubins were absent. The major isoprenoid quinone (MK-6), predominant cellular fatty acids (iso- $\mathrm{C}_{15: 1} \mathrm{G}$, iso- $\mathrm{C}_{15: 0}$ and a mixture of $\mathrm{C}_{16: 1} \omega 7 \mathrm{c}$ and/or iso- $\mathrm{C}_{15: 0} 2-\mathrm{OH}$ ) and DNA G+C content (38 mol\%) of the Antarctic isolate were consistent with those of the genus Flavobacterium. In contrast, several phenotypic characters can be used to differentiate this isolate from other flavobacteria. The polyphasic data presented in this study indicated that this isolate should be classified as a novel species in the genus Flavobacterium. The name Flavobacterium antarcticum sp. nov. is therefore proposed for the Antarctic isolate; the type strain is AT1026 $^{\top}$ (=IMSNU $14042^{\top}=$ KCTC $12222^{\top}=\operatorname{JCM} 12383^{\top}$ ).
\end{abstract}

A yellow-pigmented bacterial strain, designated AT1026 ${ }^{\mathrm{T}}$, was isolated from a terrestrial sample from the Antarctic and was the subject of taxonomic study according to the minimal standards for describing new taxa of the family Flavobacteriaceae (Bernardet et al., 2002). On the basis of polyphasic evidence, the Antarctic strain represents a novel species in the genus Flavobacterium, for which the name Flavobacterium antarcticum sp. nov. is proposed.

A soil sample was collected from a penguin habitat near the King Sejong Station on King George Island, Antarctica $\left(62^{\circ}\right.$ $\left.14^{\prime} 01 \cdot 2^{\prime \prime} \mathrm{S} 58^{\circ} 46^{\prime} 47 \cdot 4^{\prime \prime} \mathrm{W}\right)$. Isolation was carried out using marine agar 2216 (MA; Difco) at $10^{\circ} \mathrm{C}$ following enrichment for 2 days in marine broth 2216 at $4{ }^{\circ} \mathrm{C}$. The isolate was cultured routinely on R2A (Difco) at $15^{\circ} \mathrm{C}$ and maintained as a glycerol suspension $(20 \%, \mathrm{w} / \mathrm{v})$ at $-80^{\circ} \mathrm{C}$.

$16 S$ rRNA genes were enzymically amplified from a single colony. Primers, PCR conditions and sequencing methods were described elsewhere (Chun \& Goodfellow, 1995). The

Published online ahead of print on 4 October 2004 as DOI 10.1099/ ijs.0.63423-0.

The GenBank/EMBL/DDBJ accession number for the 16S rRNA gene sequence of strain $\mathrm{AT}^{1026^{\top}}$ is AY581113. sequence of strain AT1026 ${ }^{\mathrm{T}}$ was aligned manually with representative sequences of the family Flavobacteriaceae obtained from GenBank. Phylogenetic trees were inferred using the Fitch-Margoliash (Fitch \& Margoliash, 1967), maximum-likelihood (Felsenstein, 1993), maximumparsimony (Fitch, 1972) and neighbour-joining (Saitou \& Nei, 1987) methods. Evolutionary distance matrices for the neighbour-joining and Fitch-Margoliash methods were generated according to the model of Jukes \& Cantor (1969). Resultant tree topologies were evaluated by bootstrap analyses (Felsenstein, 1985) based on 1000 resamplings. Alignment and phylogenetic analyses were carried out using the jPHYDIT program (available at http:// chunlab.snu.ac.kr/jphydit) and PAUP 4.0 (Swofford, 1998) as described previously (Chun et al., 2000). An almost complete 16S rRNA gene sequence of strain AT1026 ${ }^{\mathrm{T}}$ (1406 bp) was obtained. Preliminary sequence comparison with $16 \mathrm{~S}$ rRNA gene sequences held in GenBank indicated that our isolate was related closely to the genus Flavobacterium. The newly determined sequence was then aligned manually against representatives of Flavobacterium species using bacterial 16S rRNA secondary structure. The regions available for all sequences (positions 46-1477; Escherichia coli numbering system), excluding positions likely to show ambiguous alignment (positions 76-94), were used to 


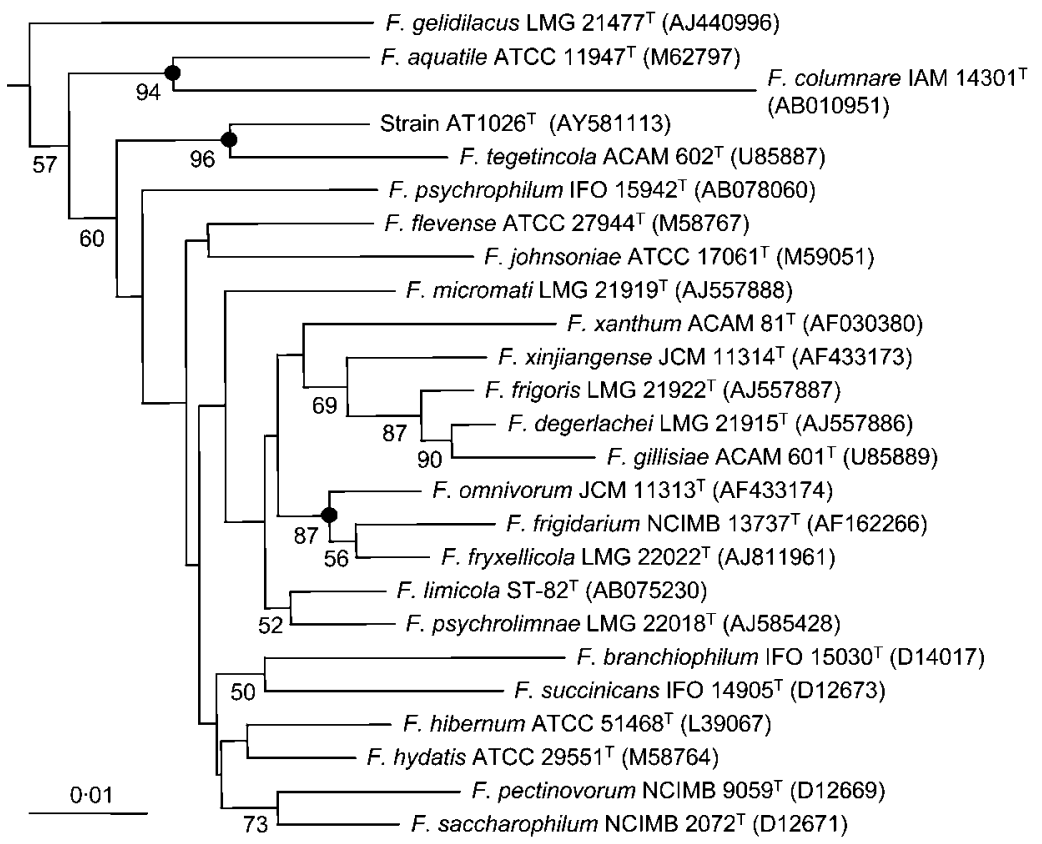

Fig. 1. Phylogenetic position of strain AT1026 $^{\top}$ within the genus Flavobacterium, based on 16S rRNA gene sequences. The tree was created using the neighbour-joining method; percentages at nodes are levels of bootstrap support ( $>50 \%$ ) from 1000 resampled datasets. Solid circles indicate that the corresponding nodes (groupings) were also recovered in Fitch-Margoliash, maximum-likelihood and maximum-parsimony trees. Cellulophaga lytica ATCC $23178^{\top}$ (M62796) was used as an outgroup (not shown). Bar, 0.01 nt substitution per position.

construct the phylogenetic trees. Based on 16S rRNA gene sequence similarity, the Antarctic isolate shared $91 \cdot 3-96 \cdot 4 \%$ similarity with members of the genus Flavobacterium and the closest bacterial relatives with validly published names were Flavobacterium tegetincola $(96 \cdot 4 \%)$. Flavobacterium flevense $(95.9 \%)$, Flavobacterium micromati $(95.6 \%)$ and Flavobacterium xinjiangense $(95 \cdot 5 \%)$. Strain $\mathrm{AT} 1026^{\mathrm{T}}$ and F. tegetincola formed a robust ( $96 \%$ bootstrap value) monophyletic clade (Fig. 1) in all trees inferred in this study, and formed a further monophyletic clade with $F$. flevense and Flavobacterium johnsoniae in Fitch-Margoliash, maximumlikelihood and maximum-parsimony trees. On the basis of our phylogenetic analysis, it is evident that our isolate is a member of the genus Flavobacterium and represents a novel genomic species.

Growth on several bacteriological media was tested; Anacker and Ordal agar [AOA; Bacto agar (Difco), $10 \mathrm{~g}$; Casitone (Difco), $0.5 \mathrm{~g}$; yeast extract (Difco), $0.5 \mathrm{~g}$; sodium acetate, $0 \cdot 2 \mathrm{~g}$; beef extract (Difco), $0 \cdot 2 \mathrm{~g}$; distilled water, $1 \mathrm{l}$, cetrimide agar (Difco), MacConkey agar (Difco), MA, nutrient agar (NA; Difco), R2A, tryptic soy agar (TSA; Difco) and sea-salt-free Zobell's agar [Bacto agar, 15 g; Bacto peptone (Difco), $5 \mathrm{~g}$; yeast extract, $1 \mathrm{~g}$; ferric citrate, $0 \cdot 1 \mathrm{~g}$; distilled water, $1 \mathrm{l}$ ]. Maximum growth was observed on R2A and abundant growth was observed on AOA, MA, NA, TSA and sea-salt-free Zobell's agar. No growth was observed on cetrimide or MacConkey agar. The temperature range for growth was determined in a temperaturegradient incubator (TVS 126MA; Advantec) using R2A broth in the range $5-35^{\circ} \mathrm{C}(5 \cdot 0,9 \cdot 7,12 \cdot 4,15 \cdot 1,17 \cdot 4,19 \cdot 6$, $21 \cdot 8,24 \cdot 1,26 \cdot 6,28 \cdot 9,31 \cdot 9$ and $35 \cdot 0^{\circ} \mathrm{C}$ ). To determine cardinal temperatures, the resultant data were fitted to the Ratkowsky temperature growth model (Ratkowsky et al., 1983 ) by non-linear regression using the R 1.8 .1 package ( $R$
Foundation for Statistical Computing, 2003). Square-root growth rate-temperature plots showed that the notional minimum, optimum and maximum growth temperatures were respectively $-14 \cdot 5,21 \cdot 2$ and $25 \cdot 1{ }^{\circ} \mathrm{C}$ (Fig. 2). When tested on R2A (between 5 and $35^{\circ} \mathrm{C}$ at $5{ }^{\circ} \mathrm{C}$ intervals), strain AT $1026^{\mathrm{T}}$ grew at $25^{\circ} \mathrm{C}$, but not at $30^{\circ} \mathrm{C}$. From the definition of Isaksen \& Jørgensen (1996), our Antarctic isolate can be defined as a psychrotolerant bacterium. The minimum doubling time of strain AT $1026^{\mathrm{T}}$ was about $4 \cdot 9 \mathrm{~h}$. Growth at different $\mathrm{pH}$ (between $\mathrm{pH} 4$ and 12 with an interval of 1) and $\mathrm{NaCl}$ concentrations [between 0 and $7 \%(\mathrm{w} / \mathrm{v})$ at $1 \%$

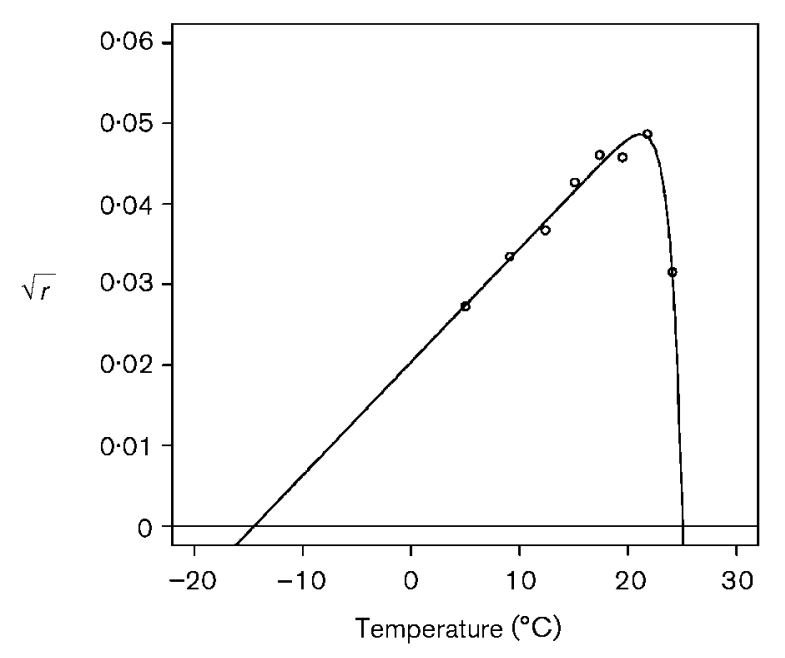

Fig. 2. Fitted Ratkowsky model of growth versus temperature data for strain AT1026 ${ }^{\top} . \sqrt{ }$ is the square-root of growth rate. The minimum, optimum and maximum temperatures are respectively $-14 \cdot 5,21 \cdot 2$ and $25 \cdot 1^{\circ} \mathrm{C}$. 
intervals] was determined using sea-salt-free ZoBell's medium. $\mathrm{KOH}$ and $\mathrm{HCl}$ (both at $6 \mathrm{M}$ ) were used to adjust the final $\mathrm{pH}$. Anaerobic and microaerophilic growth was checked under anaerobic (with 4-10\% $\mathrm{CO}_{2}$ ) and microaerobic (with 5-15\% $\mathrm{O}_{2}$ and 5-12\% $\mathrm{CO}_{2}$ ) conditions, using GasPak Plus and CampyPak Plus systems (BBL) at $15{ }^{\circ} \mathrm{C}$ for up to 1 month. The results of tests for growth conditions are given in the species description.

Morphological and physiological tests were performed using R2A as the basal medium at $15{ }^{\circ} \mathrm{C}$. Cellular morphology and motility were examined by SEM and phasecontrast microscopy using 3-, 5- and 10-day-old cells. Gliding motility was observed by direct microscopic examination of the edge of colonies in exponential phase on AOA, R2A and CY agar [casitone (Difco), 3 g; yeast extract, $1 \mathrm{~g} ; \mathrm{CaCl}_{2} \cdot 2 \mathrm{H}_{2} \mathrm{O}, 1 \mathrm{~g}$; sea salts (Sigma), $40 \mathrm{~g}$; Bacto agar, $15 \mathrm{~g}$; distilled water, $1 \mathrm{ll}$ plates, and motility was observed by the hanging drop technique for cells in exponential phase in R2A and CY broth. The presence of flexirubin-type pigments was determined by flooding the agar plate or biomass with $20 \%(\mathrm{w} / \mathrm{v}) \mathrm{KOH}$ and confirmed by measuring the absorbance spectrum of an ethanol and alkaline-ethanol extract of lysed cells (Weeks, 1981). Congo red adsorption was tested by directly flooding colonies on agar plates with $0 \cdot 01 \%$ aqueous Congo red solution.

Standard physiological and biochemical tests were performed at $15^{\circ} \mathrm{C}$ as described previously (Smibert \& Krieg, 1994). Hydrolysis of alginate $(0.5 \%, \mathrm{w} / \mathrm{v})$, casein $[50 \%$ skimmed milk (Difco), v/v], carboxymethyl cellulose $[0.5 \%$ carboxymethyl cellulose (Sigma), w/v], chitin $(0.5 \%$ colloidal chitin, w/v), egg yolk $(5 \%$, w/v), elastin $(0 \cdot 5 \%$, $\mathrm{w} / \mathrm{v})$, starch $(0 \cdot 2 \%, \mathrm{w} / \mathrm{v})$, Tween $80(1 \%, \mathrm{v} / \mathrm{v})$ and L-tyrosine $(0 \cdot 5 \%, \mathrm{w} / \mathrm{v})$ was tested using $\mathrm{R} 2 \mathrm{~A}$ as the basal medium. PEK7 agar (Reichenbach, 1991) and DNase test agar (Difco) were respectively used for pectinase and DNase assays. Production of $\mathrm{H}_{2} \mathrm{~S}$ was investigated using triplesugar iron agar (Difco). Phenylalanine deaminase activity was determined on phenylalanine agar (Smibert \& Krieg, 1994; yeast extract, 3 g; L-phenylalanine, 1 g; $\mathrm{Na}_{2} \mathrm{HPO}_{4}, 1$ g; $\mathrm{NaCl}, 5 \mathrm{~g}$; Bacto agar, $12 \mathrm{~g}$; distilled water, 1 l). Alkaline reaction on Christensen's citrate was tested on Christensen citrate agar (Christensen, 1949). Arginine dihydrolase and urease activities were determined using Thornley's semisolid medium (Thornley, 1960) and Christensen urea agar (Christensen, 1946), respectively. Acid production from carbohydrates was examined for up to 1 month using modified O/F agar plates (Leifson, 1963; casitone, $1.0 \mathrm{~g}$; yeast extract, $0 \cdot 1 \mathrm{~g}$; ammonium sulfate, $0.5 \mathrm{~g}$; Tris base, $0.5 \mathrm{~g}$; phenol red, $0.01 \mathrm{~g}$; Bacto agar, $15 \mathrm{~g}$; distilled water, $1 \mathrm{l}$; adjusted to $\mathrm{pH} 7 \cdot 0$ ). Nitrate and nitrite reduction, indole production, aesculinase, gelatinase, $\beta$-galactosidase and assimilation of sole carbon sources (glucose, arabinose, mannose, mannitol, $\mathrm{N}$-acetylglucosamine, maltose, gluconate, caprate, adipate, malate, citrate and phenylacetate) were tested using the API 20NE kit (bioMérieux), and other enzymic activities were determined using the API ZYM kit
Table 1. Characteristics that differentiate strain AT1026 from other related species

Species: 1, F. antarcticum sp. nov. AT1026 ${ }^{\mathrm{T}} ; 2$, F. tegetincola; 3, F. flevense. + , Positive; -, negative; $\mathrm{C}$, clear zone formed on eggyolk agar. Data from this study and from Bernardet et al. (1996) and McCammon \& Bowman (2000). All taxa are positive for growth on sea-water media and formation of acid from carbohydrates.

\begin{tabular}{|lccc|}
\hline Characteristic & $\mathbf{1}$ & $\mathbf{2}$ & $\mathbf{3}$ \\
\hline Gliding & - & + & + \\
Glucose utilization & $-\star$ & + & + \\
Degradation of: & & & \\
$\quad$ Gelatin & + & - & - \\
Casein & + & - & - \\
Agar & - & - & + \\
Pectin & - & - & + \\
Aesculin & - & - & + \\
DNA & + & - & - \\
Precipitate formed on egg-yolk agar & $\mathrm{C}$ & - & - \\
$\beta$-Galactosidase activity & - & - & + \\
\hline
\end{tabular}

${ }^{\star}$ On API 20NE test strip.

(bioMérieux). The results of morphological, biochemical and physiological tests are given in Table 1 and the species description.

Chemotaxonomic and genotypic characteristics were determined from cultures grown at $15^{\circ} \mathrm{C}$ on R2A. Menaquinone was isolated from 7-day-old cells according to Minnikin et al. (1984) and analysed by HPLC (Waters) as described by Collins (1985). DNA G + C content was determined by HPLC analysis of deoxyribonucleosides as described by Mesbah et al. (1989), using a reverse-phase column (Supelco). Fatty acid methyl esters analysis was performed by GLC according to the Microbial Identification (MIDI) System using 5-day-old cells. The chemotaxonomic properties of the test strain are consistent with those of the genus Flavobacterium and are given in the species description. The major fatty acid composition of our isolate is similar to those of phylogenetically related species, but differs somewhat from them in quantities (Bernardet et al., 1996; McCammon \& Bowman, 2000).

In the phylogenetic trees, our Antarctic isolate clearly belongs to the genus Flavobacterium and forms a distinct phyletic line with low 16S rRNA gene sequence similarity $(96 \cdot 8 \%)$, which indicates that it represents a novel genomic species (Stackebrandt \& Goebel, 1994). Moreover, a number of phenotypic characteristics (Table 1) readily differentiate the Antarctic strain from other related Flavobacterium species. The polyphasic data obtained in this study clearly show that the test strain merits novel species status within the genus Flavobacterium. The name Flavobacterium antarcticum sp. nov. is therefore proposed for strain AT1026 ${ }^{\mathrm{T}}$. 


\section{Description of Flavobacterium antarcticum sp. nov.}

Flavobacterium antarcticum (ant.arc'ti.cum. L. neut. adj. antarcticum southern, and, by extension, pertaining to Antarctica).

Gram-negative, oxidase- and catalase-positive and psychrotolerant. Cells are rod-shaped with rounded ends, approximately $0 \cdot 5-1 \cdot 3 \times 0 \cdot 3-0 \cdot 4 \mu \mathrm{m}$ and non-motile. Colonies are convex, translucent, glistening, butyrous, yellow, circular with entire margins and becoming mucoid after prolonged incubation on R2A and AOA. Does not glide or adhere to agar plates. Flexirubin-type pigment is absent. Congo red is not adsorbed. Spores are not formed. Growth occurs on R2A, AOA, MA, NA and TSA, but not on cetrimide or MacConkey agar. Growth is aerobic. Grows weakly under microaerobic conditions (with about 5-15\% $\mathrm{O}_{2}$ and 5-12\% $\mathrm{CO}_{2}$ created by CampyPak Plus system) and poorly under anaerobic conditions (with about $4-10 \% \mathrm{CO}_{2}$ created by GasPak Plus system). Growth occurs at pH 6-10 (optimum $\mathrm{pH} 7$ ) and $0-4 \% \mathrm{NaCl}$ (optimum $0 \%$ ). Grows at $5-24 \cdot 1{ }^{\circ} \mathrm{C}$, with notional minimum, optimum and maximum growth temperatures of $-14 \cdot 5,21 \cdot 2$ and $25 \cdot 1{ }^{\circ} \mathrm{C}$. Minimum doubling time is $4.9 \mathrm{~h}$. Decomposes Tween 80 , but not alginate, chitin, carboxymethyl cellulose, elastin, starch or tyrosine. Produces brown pigment weakly on tyrosine agar. Positive reaction for arginine dihydrolase. Negative reactions for nitrate reduction, urease, L-phenylalanine deaminase, $\mathrm{H}_{2} \mathrm{~S}$ production, indole production and alkalinization on Christensen's citrate agar. Produces acid from D-glucose and maltose, but not from D-cellobiose, D-fructose, D-mannitol, D-raffinose, D-salicin, D-trehalose, D-xylose, lactose, L-arabinose, L-rhamnose or sucrose. Alkaline phosphatase, esterase lipase (C8), leucine arylamidase, valine arylamidase, acid phosphatase and naphtholAS-BI-phosphohydrolase are positive; trypsin, $\alpha$-glucosidase and $N$-acetyl- $\beta$-glucosaminidase are weakly positive; esterase (C4), lipase (C14), cystine arylamidase, $\alpha$-chymotrypsin, $\alpha$-galactosidase, $\beta$-galactosidase, $\beta$-glucuronidase, $\beta$ glucosidase, $\alpha$-mannosidase and $\alpha$-fucosidase are negative in API ZYM kits. Cannot assimilate any of the compounds contained in API 20NE kits as sole carbon sources. Other physiological and biochemical characteristics are given in Table 1. Maximum absorption peak of pigment is at $452 \mathrm{~nm}$ and the next shoulder peak is at $479 \mathrm{~nm}$. Major isoprenoid quinone is MK-6. Predominant cellular fatty acids are iso- $\mathrm{C}_{15: 1} \mathrm{G}(15 \cdot 3 \%$; the double bond position is unknown), iso- $\mathrm{C}_{15: 0}(15 \cdot 8 \%)$ and $\mathrm{C}_{16: 1} \omega 7 \mathrm{c}$ and/or iso$\mathrm{C}_{15: 0} 2-\mathrm{OH}(10.9 \%$; the two fatty acids cannot be separated by GLC with the MIDI system). Smaller amounts of iso$\mathrm{C}_{14: 0}(2 \cdot 6 \%), \mathrm{C}_{14: 0}(2 \cdot 1 \%)$, anteiso- $\mathrm{C}_{15: 1} \mathrm{~A}(3 \cdot 3 \%$; double bond position unknown), anteiso- $\mathrm{C}_{15: 0}(6 \cdot 7 \%), \mathrm{C}_{15: 1} \omega 6 c$ $(1 \cdot 5 \%), \mathrm{C}_{15: 0}(8 \cdot 2 \%)$, iso- $\mathrm{C}_{16: 1} \mathrm{H}(3 \cdot 2 \%$; double bond position unknown), iso- $\mathrm{C}_{16: 0}(4 \cdot 1 \%)$, iso- $\mathrm{C}_{15: 0} 3-\mathrm{OH}$ $(6 \cdot 2 \%)$, iso- $\mathrm{C}_{17: 1} \omega 9 c(1 \cdot 7 \%)$, anteiso- $\mathrm{C}_{17: 1} \omega 9 c(1 \cdot 4 \%)$, iso- $\mathrm{C}_{16: 0} 3-\mathrm{OH}(4 \cdot 5 \%), \mathrm{C}_{16: 0} 3-\mathrm{OH}(2 \cdot 2 \%), \mathrm{C}_{18: 1} \omega 5 c$ $(1 \cdot 0 \%)$ and iso- $\mathrm{C}_{17: 0} 3-\mathrm{OH}(3 \cdot 0 \%)$ are also present. DNA $\mathrm{G}+\mathrm{C}$ content is $38 \mathrm{~mol} \%$.
The type strain, AT1026 ${ }^{\mathrm{T}} \quad\left(=\mathrm{IMSNU} \quad 14042^{\mathrm{T}}=\mathrm{KCTC}\right.$ $12222^{\mathrm{T}}=\mathrm{JCM} 12383^{\mathrm{T}}$ ), was isolated from a soil sample of a penguin habitat near the King Sejong Station on King George Island, Antarctica.

\section{Acknowledgements}

This work was supported by the 21C Frontier Microbial Genomics and Applications Center Program (grants MG02-0101-001-1-0-0 to S.-J. K. and MG02-0101-001-2-1-0 to J. C.), the Strategic National R\&D Program through the Genetic Resources and Information Network (grant M1-0219-00-0018), the KORDI Project (grant PP04106), KISTEP Project (grant PN50800 and PN50200) and the BK21 Research Fellowship (the Ministry of Education and Human Resources Development), Republic of Korea.

\section{References}

Bernardet, J.-F., Segers, P., Vancanneyt, M., Berthe, F., Kersters, K. \& Vandamme, P. (1996). Cutting a Gordian knot: emended classification and description of the genus Flavobacterium, emended description of the family Flavobacteriaceae, and proposal of Flavobacterium hydatis nom. nov. (basonym, Cytophaga aquatilis Strohl and Tait 1978). Int J Syst Evol Microbiol 46, 128-148.

Bernardet, J.-F., Nakagawa, Y. \& Holmes, B. (2002). Proposed minimal standards for describing new taxa of the family Flavobacteriaceae and emended description of the family. Int J Syst Evol Microbiol 52, 1049-1070.

Christensen, W. B. (1946). Urea decomposition as a means of differentiating Proteus and paracolon cultures from each other and from Salmonella and Shigella types. J Bacteriol 52, 461-466.

Christensen, W. B. (1949). Hydrogen sulfide production and citrate utilization in the differentiation of enteric pathogens and coliform bacteria, Research Bulletin no. 1. Greeley, CO: Weld County Health Department.

Chun, J. \& Goodfellow, M. (1995). A phylogenetic analysis of the genus Nocardia with $16 \mathrm{~S}$ rRNA gene sequences. Int J Syst Bacteriol 45, 240-245.

Chun, J., Bae, K. S., Moon, E. Y., Jung, S. O., Lee, H. K. \& Kim, S. J. (2000). Nocardiopsis kunsanensis sp. nov., a moderately halophilic actinomycete isolated from a saltern. Int J Syst Evol Microbiol 50, 1909-1913.

Collins, M. D. (1985). Analysis of isoprenoid quinones. Methods Microbiol 18, 329-366.

Felsenstein, J. (1985). Confidence limits on phylogenies: an approach using the bootstrap. Evolution 39, 783-791.

Felsenstein, J. (1993). PHYLIP - phylogenetic inference package, version 3.5c. Distributed by the author. Department of Genetics, University of Washington, Seattle, USA.

Fitch, W. M. (1972). Toward defining the course of evolution: minimum change for a specific tree topology. Syst Zool 20, 406-416.

Fitch, W. M. \& Margoliash, E. (1967). Construction of phylogenetic trees: a method based on mutation distances as estimated from cytochrome $c$ sequences is of general applicability. Science 155, 279-284.

Isaksen, M. F. \& Jørgensen, B. B. (1996). Adaptation of psychrophilic and psychrotrophic sulfate-reducing bacteria to permanently cold marine environments. Appl Environ Microbiol 62, 408-414.

Jukes, T. H. \& Cantor, C. R. (1969). Evolution of protein molecules. In Mammalian Protein Metabolism, vol. 3, pp. 21-132. Edited by H. N. Munro. New York: Academic Press. 
Leifson, E. (1963). Determination of carbohydrate metabolism of marine bacteria. J Bacteriol 85, 1183-1184.

McCammon, S. A. \& Bowman, J. P. (2000). Taxonomy of Antarctic Flavobacterium species: description of Flavobacterium gillisiae sp. nov., Flavobacterium tegetincola sp. nov. and Flavobacterium xanthum sp. nov., nom. rev. and reclassification of [Flavobacterium] salegens as Salegentibacter salegens gen. nov., comb. nov. Int J Syst Evol Microbiol 50, 1055-1063.

Mesbah, M., Premachandran, U. \& Whitman, W. B. (1989). Precise measurement of the $\mathrm{G}+\mathrm{C}$ content of deoxyribonucleic acid by high-performance liquid chromatography. Int J Syst Bacteriol 39, 159-167.

Minnikin, D. E., O'Donnell, A. G., Goodfellow, M., Alderson, G., Athayle, M., Schaal, A. \& Parlett, J. H. (1984). An integrated procedure for the extraction of isoprenoid quinones and polar lipids. J Microbiol Methods 2, 233-241.

R Foundation for Statistical Computing (2003). R version 1.8.1. Vienna: Vienna University of Technology.

Ratkowsky, D. A., Lowry, R. K., McMeekin, T. A., Stokes, A. N. \& Chandler, R. E. (1983). Model for bacterial culture growth rate throughout the entire biokinetic temperature range. J Bacteriol 154, 1222-1226.
Reichenbach, H. (1991). The order Cytophagales. In The Prokaryotes, pp. 3631-3675. Edited by A. Balows, H. G. Trüper, M. Dworkin, W. Harder \& K. H. Schleifer. New York: Springer.

Saitou, N. \& Nei, M. (1987). The neighbor-joining method: a new method for reconstructing phylogenetic trees. Mol Biol Evol 4, 406-425.

Smibert, R. M. \& Krieg, N. R. (1994). Phenotypic characterization. In Methods for General and Molecular Bacteriology, pp. 607-654. Washington, DC: American Society for Microbiology.

Stackebrandt, E. \& Goebel, B. M. (1994). Taxonomic note: a place for DNA-DNA reassociation and 16S rRNA sequence analysis in the present species definition in bacteriology. Int J Syst Bacteriol 44, 846-849.

Swofford, D. L. (1998). PAUP - phylogenetic analysis using parsimony, version 4. Sunderland, MA: Sinauer Associates.

Thornley, M. J. (1960). The differentiation of Pseudomonas from other gram-negative bacteria on the basis of arginine metabolism. J Appl Bacteriol 23, 37-52.

Weeks, O. B. (1981). Preliminary studies of the pigments of Flavobacterium breve NCTC 11099 and Flavobacterium odoratum NCTC 11036. In The Flavobacterium-Cytophaga Group, pp. 108-114. Edited by O. B. Weeks. Weinheim: Gesellschaft für Biotechnologische Forschung. 